\title{
Аналіз трендів розвитку науки і технологій у контексті імплементації інструментів сучасного менеджменту у процес трансформації логістики 3бройних сил України
}

\author{
Олександр Мацько ${ }^{1}$ А; Іван Гаврилюк 2 А \\ А Національний університет оборони України імені Івана Черняховського, пр-кт Повітрофлотський 28, м. Київ, 03049, Україна
}

Received: January 30, 2021 | Revised: February 26, 2021 | Accepted: February 28, 2021

DOI: $10.33445 /$ sds.2021.11.1.16

\begin{abstract}
Анотація
Результати проведеного дослідження можуть бути корисними для науковців та управлінців усіх рівнів, що досліджують та практично займаються проблематикою розвитку логістики не лише в секторі безпеки та оборони, а й у державному секторі в цілому. Систематизація літературних джерел та підходів до вирішення проблеми розвитку військової логістики засвідчила відсутність чіткого алгоритму щодо ії трансформації та розвитку. За результатами проведеного дослідження ідентифікований ряд факторів, що мають негативний вплив на розвиток логістики у Збройних Силах України. Також, у статті, проаналізовано загальний зміст логістики ЗС України, підходи до організації логістики країн-членів НАТО та сформульовані питання, що потребують першочергового вирішення. Приділено значної уваги глобальним трендам розвитку науки і технологій, що можуть бути використані у сучасній військовій логістиці. Змодельовані підходи до застосування інструментів сучасного менеджменту у логістиці ЗС України. Визначені на основі застосування сучасних інструментів менеджменту вимоги до перспективної системи логістики ЗСу із формулюванням відповідного проекту технічного завдання системи логістики.
\end{abstract}

Ключові слова: система логістики, логістика Збройних Сил України, військова логістика, інструменти логістики.

\section{Постановка проблеми}

Із початком бойових дій на Сході України Збройні Сили України перебували у низькому боєздатному стані, про що свідчила низька укомплектованість особовим складом, озброєнням та військовою технікою. Запаси матеріальних засобів не відповідали нормам, мали місце проблеми організаційно-технічного та фінансового характеру.

Наявна на той час система Логістики Збройних Сил України (ЗС України) виявилась обмежено-спроможною виконувати завдання в ході проведення антитерористичної операції (АТО) та у подальшому в операції Об'єднаних сил (OOC) [1].
Механізм функціонування Логістики ЗС України потребує системного перегляду із послідуючим науково-обгрунтованим формулюванням відповідних рекомендацій щодо підвищення ії ефективності та адаптивності до умов сучасної невизначеності [2-5].

3 метою досягнення стратегічних цілей і виконання основних завдань, визначених Стратегічним оборонним бюлетенем України та Державною програмою розвитку 3бройних Сил України на період до 2020 року у ЗС України продовжується планова поетапна робота щодо впровадження реформ, спрямованих на створення єдиної ефективної системи логістики

\footnotetext{
${ }^{1}$ Corresponding author: к.в.н., професор, начальник інституту забезпечення військ (сил) та інформаційних технологій, е-таil: macko2006@ukr.net, ORCID: 0000-0003-3415-3358

2 к.в.н., старший науковий співробітник відділу логістичних досліджень, e-mail: ivan.havryliuk@gmail.com
} 
за стандартами НАТО та визначені основні етапи цього складного процесу [6-9].

Також, постановка проблеми зумовлена й актуальністю проведення дослідження, що підтверджується виконанням стратегічної мети щодо об'єднання системи логістики і системи медичного забезпечення, які здатні надавати підтримку усім складовим сил оборони відповідно до Річної національної програми під егідою Комісії Україна - НАТО на 2020 рік [10], затвердженої Указом Президента України від 26 травня 2020 року № 203/2020.

У процесі вирішення зазначеного завдання виникають досить вагомі перепони на шляху до пошуку стратегічних, концептуальних, функціональних, економічних та інших підходів (інструментів).

Як свідчить досвід проведення ООС [11-12], вирішення вказаних вище завдань дало змогу сформулювати ланцюг взаємопов'язаних невідповідностей та протиріч, виявлених в ході організації логістики.

Викладене зумовлено, в першу чергу, відсутністю обґрунтованої стратегії на етапах створення та трансформації єдиної системи логістики зСУкраїни. I саме тому, наукове обґрунтування перспективної трансформації єдиної системи логістики в ЗС України, у період іï становлення, набуває першочергового значення.

\section{Аналіз останніх досліджень та публікацій}

У фаховій літературі такі управлінці та науковці як: Г. Кривогуз [13], О. Нагорнічевський [14], Ю. Пунда, М. Гребенюк [15], І. Павловський, В. Твердохлібов, О. Башкиров [16], В. Саган [17] , В. Василевський, що висвітлюють проблеми становлення та розвитку логістики в Україні, переважно досліджують зарубіжний досвід застосування логістичних підходів. Пропозиції щодо розв'язання деяких проблем та основні положення становлення фундаментальних теоретичних положень формування логістичних систем висвітлюються у наукових працях: О. Наконечного [18], Н. Чорнописької, О. Бреня, О. Данильціва [19].

Проблеми та перспективи розвитку логістичного забезпечення ЗС України відображені В працях В. Беляченка, С. Боброва [20], М. Заклада, В. Кивлюка [21], В. Лози [22], І. Неурова [23], Ф. Педана, І. Романченка, О. Романченка [24], В. Серватюка, М. Утюшева, В. Шуєнкіна. Аналізу організації матеріально-технічного забезпечення збройних сил провідних держав присвячено статті І. Власова, А. Сумця [25] та ін.

Розвиток сучасної логістики відбувається синхронізовано у відповідності із викликами, що стоять перед збройними силами.

Нормативно-правові та розпорядчі документи, що регулюють питання всебічного функціонування логістики В ЗС України, у тому числі органів військового управління (Головне управління логістики (ГУЛ), Командування сил логістики (КСЛ) зС України) досить поверхнево формулюють вектор розвитку логістики в ЗС України, як на етапах їі створення, так і на довгострокову перспективу [26, 27].

Так, наказом Міністерства оборони України від 11 жовтня 2016 року № 552 “Про затвердження Основних положень логістичного забезпечення Збройних Сил України" визначена концепція створення логістичного забезпечення ЗС України [28], яка у свою чергу регламентує порядок об'єднання функціональних структур із функціями матеріально-технічного, технічного, тилового, фінансового та інших видів забезпечення в структуру єдиного логістичного забезпечення.

Разом 3 тим, зазначеним наказом не визначена концепція трансформації запропонованої системи протягом конкретних етапів ії створення.

Таким чином, в процесі трансформації логістики ЗС України не врегульовано питання першочергових заходів на етапах їі реформування та порядок застосування інструментів сучасного менеджменту, і як наслідок, слабке уявлення вектору розвитку логістики ЗС України, механізму ії 
функціонування та перспективної структури.

Наявна практика із зазначеного питання свідчить, що відсутність чіткого алгоритму створення логістики ЗС України не дасть змогу забезпечити своєчасне виконання державного завдання щодо створення ефективної логістики зС України та їі синхронізацію із відповідними структурами НАТО.

\section{Постановка завдання}

Метою статті $\epsilon$ аналіз трендів розвитку науки і технологій щодо можливості застосування найкращих практик (інструментів) сучасного менеджменту у процес трансформації логістики ЗС України.

Для забезпечення досягнення мети статті пропонується провести декомпозицію мети наукового дослідження та частково:

1. Проаналізувати загальний зміст логістики ЗС України, сформулювати питання, що потребують першочергового вирішення.

2. Проаналізувати глобальні тренди розвитку науки і технологій, що можуть бути використані у сучасній військовій логістиці.

3. Визначити на основі застосування сучасних інструментів менеджменту вимоги до перспективної системи логістики зСУ із визначенням відповідного проекту технічного завдання системи логістики.

\section{Виклад основного матеріалу}

Створенню системи логістики зС України, здатної до функціонування у будь-яких умовах обстановки, як в середині держави, так і за їі межами, передувало визначення її змісту.

Візія логістики ЗСУкраїни визначена як система, що ефективна, інтегрована в державну систему логістики та сумісна 3 логістичними системами збройних сил держав-членів НАТО.

Місія логістики ЗС України - постачання необхідних матеріальних засобів, в потрібне місце, в потрібний час, для повного забезпечення потреб військ 3 метою гарантованого виконання ЗС України завдань з оборони держави;

До цінностей логістики ЗС України слід віднести: патріотизм, професійність, відповідальність. Споживачем (межа системи) визначена бойова одиниця (взвод, відділення, розрахунок, екіпаж).

Виконання місії можливе завдяки поетапному i збалансованому створенню системи логістики ЗС України 3 поступовим нарощенням ії спроможностей до 2025 року, але аналіз джерел використаних у даному досліджені свідчить про наявність питань, що потребують першочергової уваги:

наявність гострої необхідності у створенні сучасної системи забезпечення потреб сил оборони нашої держави, здатної виконувати завдання для підтримання дій збройних сил партнерів, як в миротворчих операціях так і на території України;

залежність функціонування системи логістики ЗС України як підсистеми від більш ширших систем логістики держави (система забезпечення держави в особливий період, матеріальний резерв держави, мобілізаційні завдання підприємств всіх форм власності), системи функціонування ЗС України, яка в свою чергу $\epsilon$ підсистемою в системі сектору безпеки і оборони України. Функціонування системи логістики ЗСУкраїни охоплює широкий спектр діяльності, як складової системи логістики держави з одночасним функціонуванням в структурі ЗС України;

наявність слабкої динаміки в економічному розвитку держави, розбалансований оборонно-промисловий комплекс, часткова спроможність економіки держави забезпечити функціонування в умовах особливого періоду та обмежене фінансування ЗС України.

Побудова системи логістики ЗС України, як складової системи логістики держави, 3 урахуванням світового досвіду та міжнародних стандартів функціонування логістики збройних сил НАТО є складовою процесу інтеграції України в сучасну структуру міжнародних економічних та політичних відносин. 
Тому, сьогодні, перед українською державою постало непросте питання вибору: прийняти виклики глобалізації і включитися у жорстку конкуренцію на світових ринках, реформувавши економіку та інституційне управління державою, чи бути відкинутою на узбіччя цивілізаційних процесів.

Активізація зусиль по створенню високофункціональної системи логістики ЗС України неодмінно пов'язана із загальним розвитком національної економіки та зміцненням воєнно-економічної безпеки. Європейська інтеграція, є одним із ключових стратегічних напрямів розвитку України.

Вагоме значення для розвитку системи логістики має участь України у миротворчих операціях під егідою ООН, НАТО та інших міжнародних організацій. Україна має досвід участі в операціях під егідою НАТО в Боснії та Герцеговині, Косові, Македонії, Іраку, Афганістані, а також в Середземному морі та Індійському океані. Законодавством України визначено, що така участь $€$ однією із важливих складових зовнішньої політики та напрямком забезпечення національної безпеки держави та відповідає національним інтересам України [29].

Усе вище перелічене має суттєвий вплив і на військову логістику, тому виникає нагальна необхідність у аналізі трендів розвитку науки і технологій у предметній області дослідження:

1. Перехід на цифровий ланцюжок поставок [30], який включає процеси:

відслідковування рівня запасів в реальному часі;

взаємодію споживачів із матеріальними засобами;

розташування операторів та обладнання; використання цієї інформації для планування та підвищення рівня продуктивності.

Такі технології, як GPS-відстеження, радіочастотна ідентифікація (RFID) [31,32], штрих-коди, смарт-мітки, дані визначення місця розташування та бездротові сенсорні мережі, відіграють визначальну роль у цифровому ланцюжку поставок.

Потенційні вигоди від повністю реалізованого цифрового ланцюжка поставок включають заощадження ресурсів, часу, грошей, а також збільшення прибутку та зниження впливу на навколишнє середовище.

2. Передове виробництво $€$ ще одним важливим напрямком в логістиці, ключовим аспектом якого $€$ 3D друк. Принтери розташовуються ближче до району виконання завдань, що зменшує вимоги до виробництва, зберігання та зменшує лінії постачання. 3D принтери можуть бути прикріплені до бойових підрозділів від батальйону і вище, або навіть встановлені на певному обладнанні (наприклад, бойовий корабель). Ця децентралізація виробництва запасних частин підвищує мобільність i готовність військ, оскільки вони стають менш залежними від "логістичного хвоста".

3. Широке використання в армії автономних транспортних засобів та безпілотних літальних апаратів для вирішення завдань логістики.

Автономні транспортні засоби (АТЗ) та безпілотні літальні апарати (БПЛА) дозволять виконувати логістичні завдання із залученням меншої кількості військовослужбовців, забезпечать підвищення швидкості, точності і пропускної здатності логістики, тим самим значно покращуючи функцію бойових дій. Зазначене неодмінно зменшить бойові втрати серед військовослужбовців особливо безпосередньо в районах бойових дій. Зазначені АТЗ та БПЛА також будуть використовуватись під час розгортання i переміщення військ у зони бойових дій, або їх евакуації та можуть служити в гуманітарних місіях і місіях з ліквідації наслідків катастроф [33].

Для забезпечення сумісності з НАТО в інформаційному просторі, науковими установами України та ЗС України ведеться активна робота щодо створення автоматизованих систем управління військами (силами) на базі сучасних рішень типу C4ISR (Command, Control, Communications, Computers, Intelligence, Surveil, lance and Reconnaissance), в яких функції людини замінюються інтелектуальними системами, навіть в межах прийняття певних рішень. 
Для розуміння вектору розвитку системи логістики ЗС України необхідно провести огляд найкращих практик функціонування системи логістики у збройних силах деяких країн-членів НАТО, та її союзників.

Логістика збройних сил провідних держав світу ґрунтується на особливостях стратегії їх застосування, визначеної національними військовими доктринами, економічних можливостях держави, статусу держав, оперативних спроможностей збройних сил та перспектив їх розвитку (реформування).

Так, в армії США логістика повинна бути спроможною:

забезпечити дії військ (сил), що залучаються до підготовки оборони території держави та в операціях, які носять експедиційний характер;

забезпечити дії військ (сил) разом із збройними силами держав-союзників, шляхом досягнення взаємосумісності В організації процесів логістичного забезпечення та оснащенні ОВТ, що $є$ у арміях країн-партнерів [34].

Логістика збройних сил Ізраїлю будується з урахуванням особливостей їх застосування у військових конфліктах з різним ступенем інтенсивності ведення бойових дій вздовж периметру кордону держави, відсутності територіальної стратегічної глибини, невеликих людських та матеріальних ресурсів. Крім того, логістика збройних сил Ізраїлю повинна бути у готовності здійснювати їх забезпечення у разі ведення ними превентивної війни на території противника [35].

у збройних силах Республіки Польщі (РП) сутність логістичного забезпечення військ виражається в підготовці відповідно скерованого та розміщеного просторово матеріального, технічного, медичного і транспортного потенціалу, а також забезпечення можливостей їх раціонального використання (при одночасному широкому використанні місцевої логістичної інфраструктури) з метою створення умов для результативного проведення операцій різного виду [36].

Загалом система логістики НАТО включає в себе зберігання та підтримку матеріальнотехнічних засобів у працездатному стані, засоби автотранспорту, транспортування поранених і хворих, їх розміщення у лазареті, будівництво споруд військового призначення, логістичні мережі та адміністративна діяльність застосовується в основному у великих військових з'єднаннях, а у військових частинах, починаючи від корпусу і нижче, виконується тільки функція забезпечення.

Забезпечення здійснюється за трьома напрями:

підвезення, евакуація i збереження у справності матеріально-технічних засобів)

медико-санітарне забезпечення (лікування, евакуація i розміщення в шпиталях поранених та хворих);

грошове забезпечення, польова пошта та інше.

3 метою вчасного оперативного забезпечення підрозділів майном проєктуються спеціальні шляхи забезпечення, котрі охоплюють шляхи безпосередньо від бази забезпечення до місця ведення бойових дій. Ці логістичні схеми утворюються за рахунок мобільних підрозділів і частин забезпечення, а також стаціонарних пунктів забезпечення. Виконання різноманітних бойових завдань сплановані таким чином, щоб логістичні центри та підрозділи встигали своєчасно забезпечити якісне їх виконання, збереження матеріальнотехнічних засобів і медико-санітарного майна.

Характерною особливістю логістики збройних сил держав-членів НАТО $\epsilon$ трирівнева система забезпечення та застосування єдиної системи класифікації і кодифікації матеріальних засобів [37].

За результатами проведеного огляду можна зробити попередній висновок, що стратегія збройних сил республіки Польщі більш універсальна для застосування у Збройних Силах України.

Так, для логістики ЗС України $є$ актуальним та першочерговим до впровадження: єдиний понятійний апарат; структура ОВУ; центр координації перевезень; трирівнева система забезпечення; регіональний розподіл сил i засобів логістики; класи постачання матеріальних засобів; інформаційна система 
підтримки логістичних процесів; отримання продукції та послуг від комерційних структур за аутсорсингом.

Разом з тим, з огляду на загрозу з боку Російської Федерації, існує необхідність створення складської інфраструктури (системи) захищеного типу для забезпечення живучості, а також розвитку річкового флоту для забезпечення функціонування системи логістичного забезпечення на бар'єрних рубежах.

Для створення даної системи впроваджено метод клієнтського виміру, в якому враховано вимоги всіх клієнтів, які сфокусовані на споживачеві та побудовані за логікою запуску попереднім клієнтом наступного [38].

Фрагмент методу клієнтського виміру наведений в таблиці (Табл. 1).

Таблиця 1- Клієнтський вимір

\begin{tabular}{|c|c|c|c|}
\hline Клієнт & Роль & Потреба ролі & Пропозиція цінності \\
\hline \multirow{4}{*}{$\begin{array}{l}\text { Менеджер } \\
\text { (впровадження } \\
\text { нової концепції, } \\
\text { сумісність з } \\
\text { НАТО, } \\
\text { спроможність) }\end{array}$} & \multirow{4}{*}{$\begin{array}{l}\text { Генеральний } \\
\text { штаб } \\
\text { (Головне } \\
\text { управління } \\
\text { логістики) }\end{array}$} & \multirow{2}{*}{$\begin{array}{l}\text { Розроблення стратегії } \\
\text { створення системи } \\
\text { логістичного } \\
\text { забезпечення ЗСУ }\end{array}$} & $\begin{array}{l}\text { Впровадження нової концепції в } \\
\text { систему всебічного забезпечення військ }\end{array}$ \\
\hline & & & $\begin{array}{l}\text { Сумісність системи забезпечення військ } \\
\text { зі стандартами НАТО }\end{array}$ \\
\hline & & \multirow[t]{2}{*}{$\begin{array}{l}\text { Супроводження } \\
\text { реалізації стратегії }\end{array}$} & $\begin{array}{ll}\text { Поступове } & \text { нарощування } \\
\text { спроможностей системи забезпечення } \\
\text { військ }\end{array}$ \\
\hline & & & $\begin{array}{l}\text { Забезпечення ефективності приймаємих } \\
\text { рішень }\end{array}$ \\
\hline \multicolumn{2}{|c|}{ Головнокомандувач ЗСУ } & $\begin{array}{l}\text { Боєздатні ЗСУ готові до } \\
\text { виконання завдань за } \\
\text { призначенням }\end{array}$ & Забезпечено обороноздатність держави \\
\hline
\end{tabular}

Аналогічна побудова для інших клієнтів: провайдерів державної політики, експертів, лобістів, розробників інфраструктури, інвесторів, виробників, утримувачів запасів, постачальників військ, споживачів.

Результатом чого $\epsilon$ отримання максимальної цінності для кінцевого споживача. За межами клієнтського виміру знаходиться Головнокомандувач ЗС України
(Табл. 1), який оцінює ефективність роботи системи логістики як складової системи зС України.

За результатами аналізу клієнтського виміру розроблений проект технічного завдання системи логістики. Фрагмент проекту технічного завдання системи логістики наведений в таблиці (Табл. 2).

\section{Таблиця 2 - Проект технічного завдання системи логістики}

\begin{tabular}{|c|c|c|c|c|c|}
\hline Клієнт & Потреба ролі & Технічне завдання & Виконується? & Ресурси & $\begin{array}{c}\text { Хто буде } \\
\text { виконувати? }\end{array}$ \\
\hline $\begin{array}{l}\frac{0}{0} \\
\frac{5}{5} \\
\frac{1}{x} \\
\frac{2}{2}\end{array}$ & $\begin{array}{l}\text { Розроблення стратегії } \\
\text { створення системи } \\
\text { логістичного } \\
\text { забезпечення ЗСУ }\end{array}$ & $\begin{array}{l}\text { Надати необхідний } \\
\text { доступ до } \\
\text { інформації, } \\
\text { забезпечити } \\
\text { ефективну } \\
\text { комунікацію }\end{array}$ & так & - & $\begin{array}{c}\text { ГУ логістики } \\
\text { ГШ ЗСУ }\end{array}$ \\
\hline 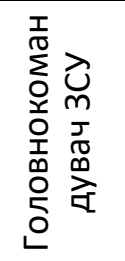 & $\begin{array}{lr}\text { Боєздатні } & \text { 3СУ готові } \\
\text { до } & \text { виконання } \\
\text { завдань } & \text { за } \\
\text { призначенням }\end{array}$ & $\begin{array}{l}\text { Забезпечення } \\
\text { боєздатності ЗСу }\end{array}$ & так & $\begin{array}{c}\text { Органи } \\
\text { управління, } \\
\text { сили і засоби } \\
\text { логістичного } \\
\text { забезпечення. }\end{array}$ & $\begin{array}{c}\text { ГУ логістики } \\
\text { ГШ, КСЛ ЗСУ, } \\
\text { логістика } \\
\text { видів (ОК) ЗСУ }\end{array}$ \\
\hline
\end{tabular}


Яке відпрацьовано з урахуванням потреб ролей клієнтів, ресурсів, із визначенням головних виконавців. Створення складових продукту покладається на відповідних клієнтів.

Система логістичного забезпечення 3С України повинна мати ієрархічні рівні, а саме: від тактичного, оперативного до стратегічного. Логістика стратегічного рівня $\epsilon$ вищою ланкою в системі забезпечення 3 С матеріальними ресурсами. Виходячи з цього, стратегічною метою системи логістичного забезпечення $є$ створення гнучкої, надійної та економічної

ЗС України.

Стратегічна мета реалізується через створення перспективної системи (Рис. 1), особливістю якої $\epsilon$ поєднання моделі ієрархічно підпорядкованої за вертикаллю від стратегічного до тактичного рівнів військового управління в ЗСУкраїни, із системною логікою, де враховуються цінності кожного окремого учасника. Лідером даної перспективної системи є Головне управління логістики Генерального штабу ЗС України.

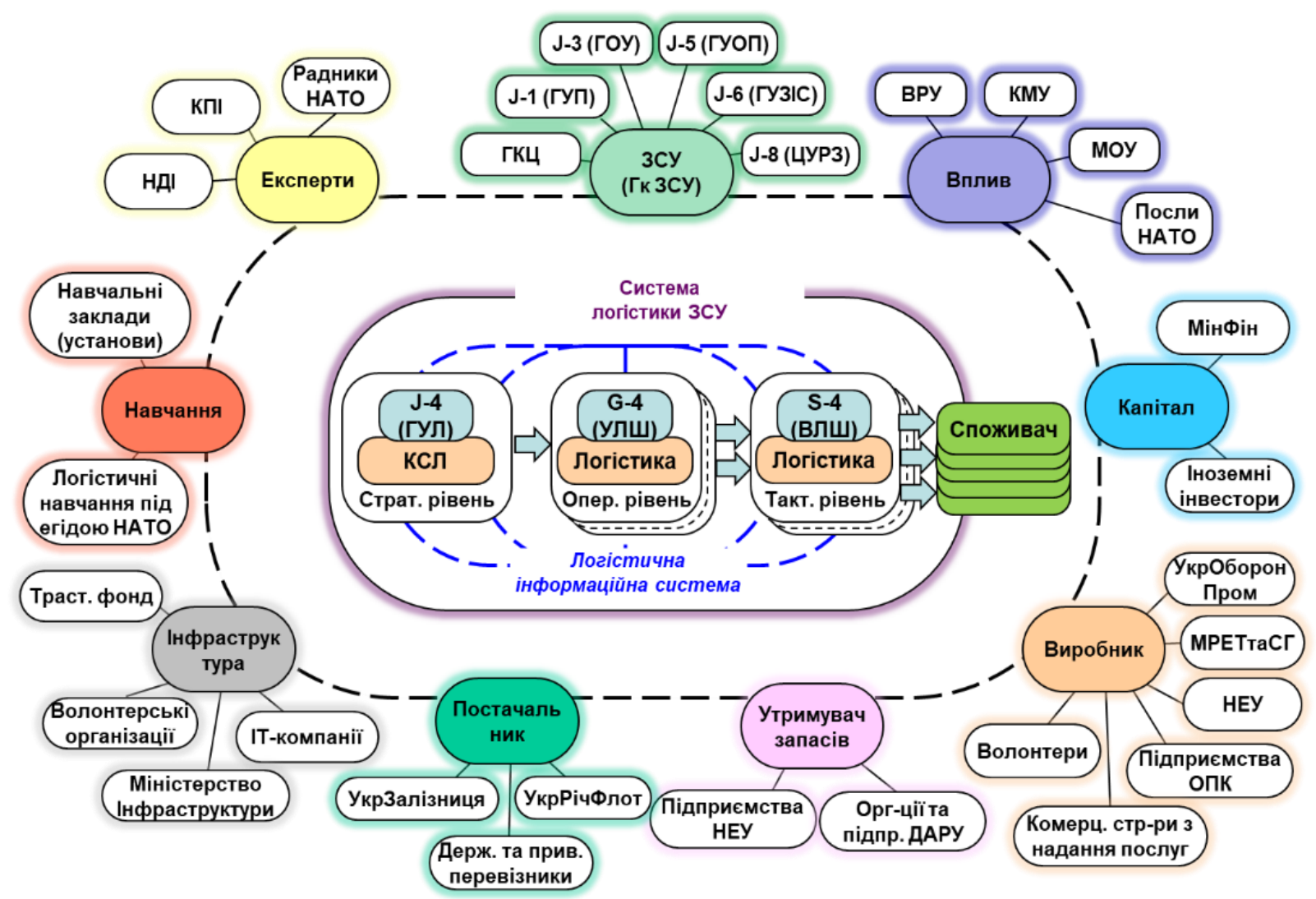

Рисунок 1 - Схема перспективної системи логістики ЗСУ

Зазначена система враховує посилення інтересів одного учасника іншим, наприклад, інтереси утримувача запасів посилюють інтереси виробника, або постачальника - інфраструктурою тощо. Управління партнерами та відносинами між ними в системі здійснюється через баланс інтересів (Табл. 3), який враховує їх вкладу у систему.

Таблиця 3 - Баланс інтересів

\begin{tabular}{|l|l|l|l|}
\hline $\begin{array}{c}\text { № } \\
\text { 3/п }\end{array}$ & \multicolumn{1}{|c|}{ Гклад в екосистему } & \multicolumn{1}{|c|}{ Інтереси гравця } \\
\hline 1 & Головнокомандувач 3СУ & $\begin{array}{l}\text { Прийнятт рішень щодо } \\
\text { розвитку системи логістики } \\
\text { ЗСУ. }\end{array}$ & $\begin{array}{l}\text { Забезпечення гарантованого } \\
\text { виконання 3СУ завдань з оборони } \\
\text { Держави, розвиток системи } \\
\text { логістики зСУ за стандартами } \\
\text { НАТО. }\end{array}$ \\
\hline
\end{tabular}


ISSN 2522-9842 Journal of Scientific Papers "Social Development and Security", Vol. 11, No. 1, - 2021

\begin{tabular}{|c|c|c|c|}
\hline $\begin{array}{l}\text { № } \\
3 / \pi\end{array}$ & Гравець & Вклад в екосистему & Інтереси гравця \\
\hline 2 & Держави-члени НАТО & $\begin{array}{l}\text { Підтримка створення } \\
\text { системи логістики ЗСу у } \\
\text { відповідності до стандартів } \\
\text { НАТО. }\end{array}$ & $\begin{array}{l}\text { Взаємосумісна система логістики } \\
\text { зСу з системами логістики } \\
\text { держав-членів НАТО, участь у } \\
\text { забезпеченні сил та організацій } \\
\text { НАТО під час проведення } \\
\text { операцій під проводом Альянсу, } \\
\text { як на території України так і поза їі } \\
\text { межами. }\end{array}$ \\
\hline 3 & $\begin{array}{l}\text { Транспортно- } \\
\text { логістичний кластер }\end{array}$ & $\begin{array}{lr}\text { Виробництво, утримання та } \\
\text { постачання } & \text { ОВТ і } \\
\text { матеріальних } & \text { засобів до } \\
\text { військ, їх } & \text { технічне } \\
\text { обслуговування } & \text { та ремонт, } \\
\text { перевезення } & \text { військових } \\
\text { пасажирів та } & \text { військових } \\
\text { вантажів. } & \\
\end{array}$ & $\begin{array}{l}\text { Розвиток підприємств, отримання } \\
\text { прибутків, можливість виходу на } \\
\text { міжнародний ринок постачання } \\
\text { товарів та послуг військового } \\
\text { призначення, зріст інноваційноїта } \\
\text { інвестиційної привабливості. }\end{array}$ \\
\hline
\end{tabular}

Для визначення подальшої роботи із Влади та інтересів, та визначено чотири складовими системи, використано матрицю напрямки співпраці з ними (Рис. 2).

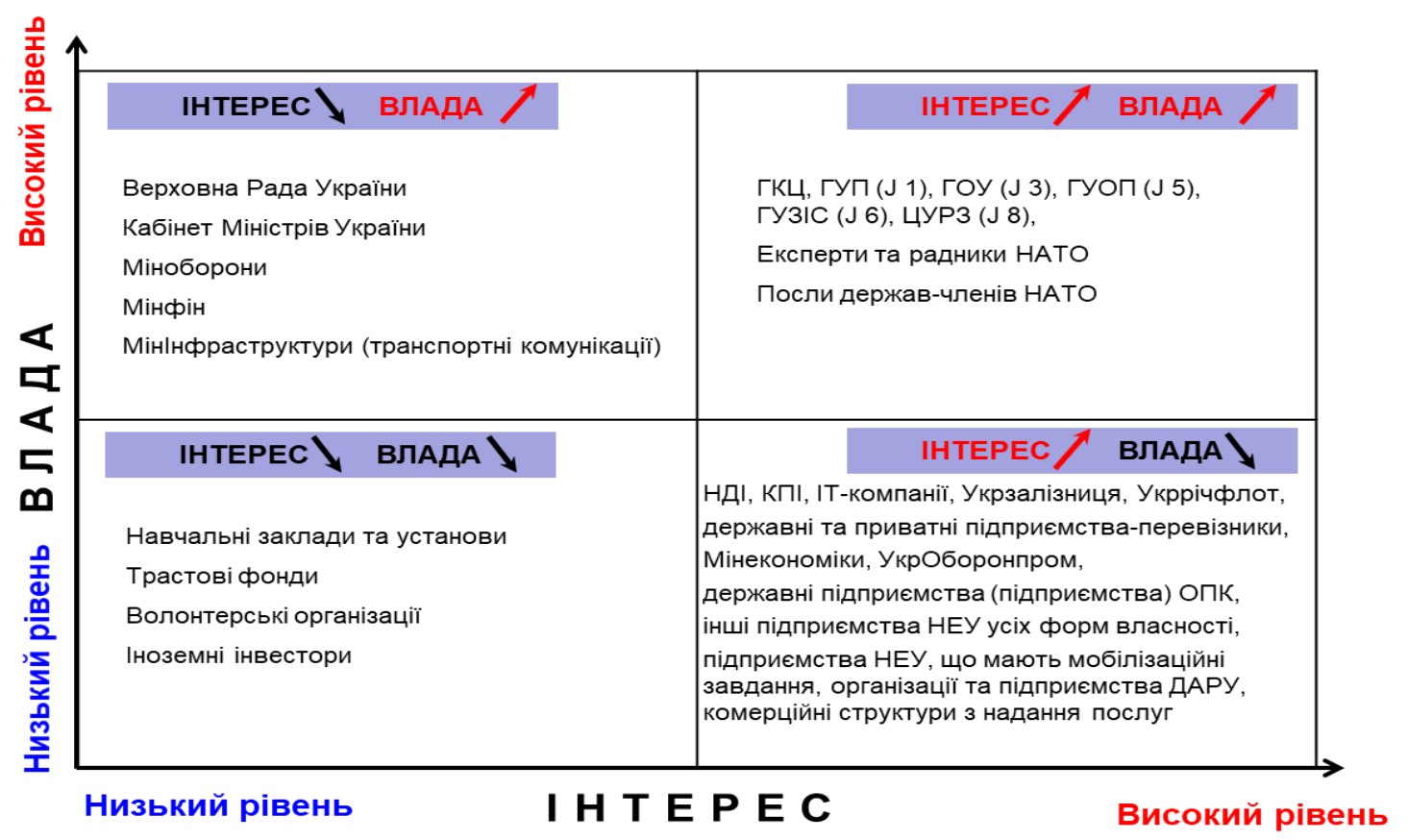

Рисунок 2 - Матриця Влади та Інтересів екосистеми логістики ЗС України

Аналіз матриці дає змогу зрозуміти відношення кожної складової системи до ії функціонування:

1. Від кого слід збирати вимоги до системи?

2. Які сторони слід розглядати як джерело ризику для проекту?

3. Кого слід залучити до розвитку системи?

4. Хто зацікавлений у функціонуванні та розвитку системи?
Проте, запропоновані в матриці стратегії роботи із зацікавленими сторонами, не $\epsilon$ остаточними та потребуватиме періодичного оновлення відповідно до проміжних результатів функціонування системи.

Реалізація пропозиції цінності та визначення чітких взаємовідносин між клієнтами в екосистемі візуалізовано у Value Net (Pис.3). 


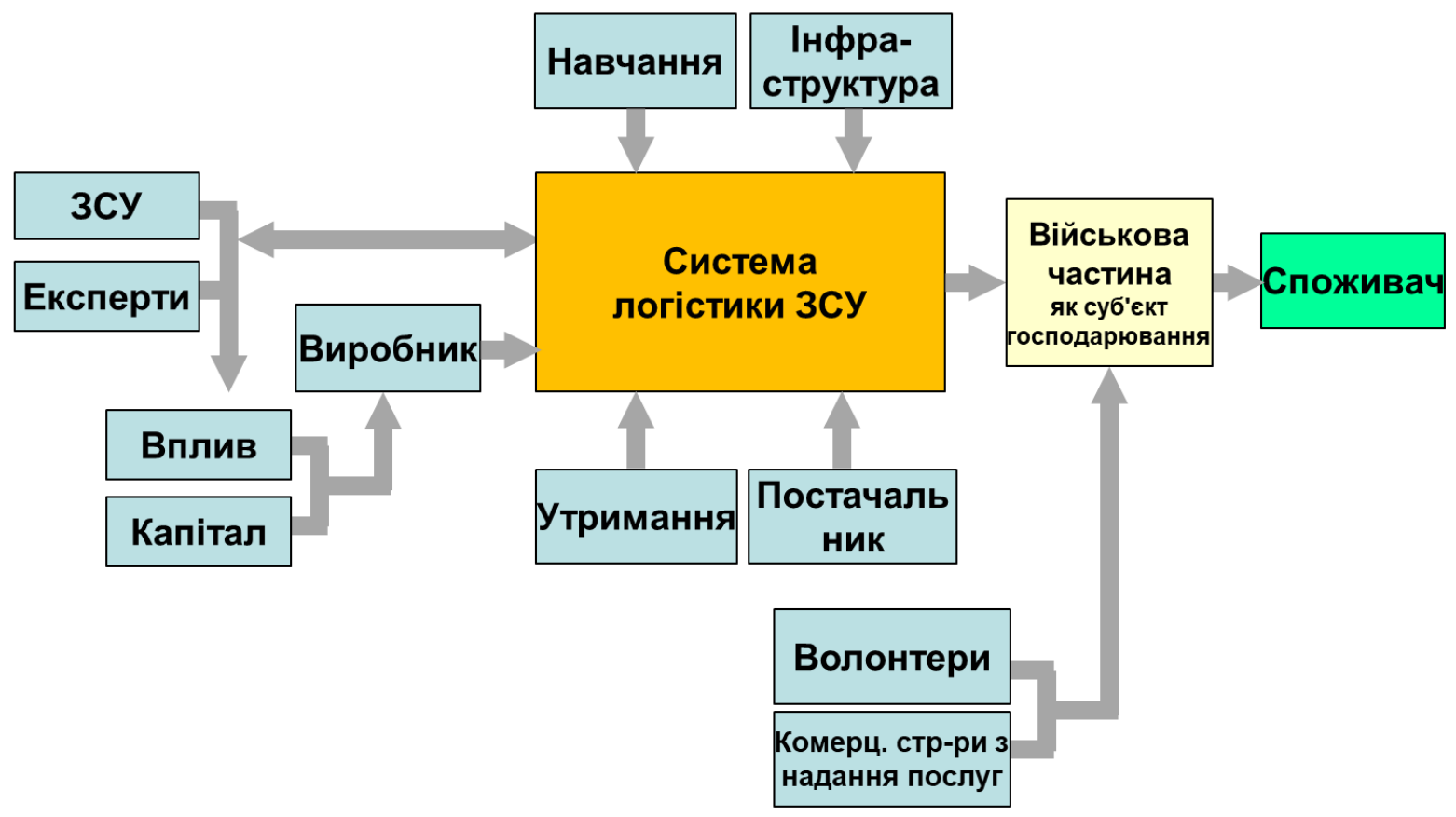

Рисунок 3 - Візуалізація Value Net

Для виконання стратегічної ідеї відпрацьовано проект бізнес моделі, через яку реалізуються пропозиції цінностей клієнтів 3 урахуванням ключових процесів та ресурсів, основаної на нових культурних відносинах та надає високу економічну ефективність функціонування системи. При цьому, стратегічний контроль здійснюється через управління Value Net та організаційну культуру.

Впровадження бізнес-моделі слід здійснювати за етапами:

перший - нормативно-правове врегулювання функціонування системи логістики зСУкраїни та проведення експерименту в пілотній зоні на базі одного 3 транспортно-логістичних кластерів;

другий - створення системи логістики на тактичному рівні та впровадження автоматизації процесів управління логістичним забезпеченням;

третій - завершення формування цілісної системи забезпечення діяльності ЗС України та набуття визначених спроможностей.

\section{Висновки}

Підводячи підсумок, необхідно зазначити, що проведений аналіз трендів розвитку науки і технологій засвідчив наявність широкого кола інструментів сучасного менеджменту, що може та повинен бути імплементований у розвиток логістики $3 \mathrm{C}$ України. Застосування у військовій логістиці найкращих світових практик предметної сфери надасть потужного поштовху у досягненні рівня функціонування логістики країн-членів НАТО.

Деталізуючи викладене, урахування досвіду логістичного забезпечення провідних держав дозволить поступово перейти до сучасної, цілісної та єдиної системи логістичного забезпечення ЗС України.

Для продуктивного розвитку системи логістики ЗС України необхідно:

широке використання інструментів сучасного менеджменту у предметній сфері;

повна ситуаційна обізнаність про ресурси в режимі реального часу,

своєчасне реагування на поточні та прогнозовані потреби військ, швидка i адресна доставка ресурсів,

гнучка адаптація системи матеріальнотехнічного забезпечення до умов реальної обстановки.

Так, для логістики 3С України буде притаманним: єдиний понятійний апарат; 
структура органів військового управління; центр координації перевезень; трирівнева система забезпечення; регіональний розподіл сил і засобів логістики; класи постачання матеріальних засобів; інформаційна система підтримки логістичних процесів; отримання продукції та послуг від комерційних структур за аутсорсингом.

Перспективи подальших досліджень вбачаються у: розробленні інформаційної

системи логістики ЗС України;

регламентації вимог та стандартів;

аналізу зовнішніх та внутрішніх факторів, що впливають на систему логістики ЗС України;

розвитку спроможностей системи логістики та наукове супроводження (обґрунтування).

\section{Список використаних джерел}

1. Шляхи створення єдиної системи логістики Збройних Сил України за досвідом локальних війн та проведення антитерористичної операції, науково-практичний семінар кафедри тилового забезпечення, Тези доповідей, інв. 9188, 2018, 80 с.

2. Kivlyuk, V., Tkach, M., Loishyn, A., \& Gannenko, Y. (2019). Improvement of educational activities in order to develop the logistics system of the Armed forces of Ukraine. Journal of Scientific Papers "Social Development and Security», 9(6), 112-124. DOI: 10.33445/sds.2019.9.6.9

3. Kyvliuk, V., \& Gannenko, Y. (2018). Improvement of the system of material resources of the armed forces of Ukraine. Journal of Scientific Papers "Social Development and Security", 4(2), 49 - 58. DOI: 10.5281/zenodo.1231404

4. Дачковський В. О. Концептуальні основи управління потоками в системі логістичного забезпечення Збройних Сил України / В.О. Дачковський, І.Ю. Гаврилюк, О.Й. Мацько // науковий журнал “Сучасні інформаційні технології у сфері безпеки та оборони", HУOУ. - 2019. - № 1(34) С. 37 - 44.

5. Заклад М. А. Аналіз функціонування системи логістики у провідних країнах світу. Сучасні інфрормаційні технології у срері безпеки та оборони. 2019. №3(36).

6. Про Стратегічний оборонний бюлетень України: Указ Президента України від 20 травня 2016 р. № 240/2016. URL: https://www.president.gov.ua/documents/24 02016-20137 (дата звернення 30.12.2020).

7. Про Державну програму розвитку Збройних Сил України на період до 2020 року: Указ
Президента України від 22 березня 2017 р. № 73/2017: URL https://zakon.rada.gov.ua/ laws/show/n0017525-16 (дата звернення 30.12.2020).

8. NATO Logistics Handbook/-Brussels: NATO HQ, 2012. 210.,

9. Christopher R. Paparone, "Defining Analytics and Its Supporting Role in Military Logistics Intelligence". Christopher R. Paparone and George L. Topic Jr / Army Sustainment, September-October 2015.

10. Річна національна програми під егідою Комісії Україна - НАТО на 2020 рік: Указ Президента України від 26 травня 2020 року № 203/2020. URL: https://www.president. gov.ua/documents/2032020-33861 (дата звернення 30.12.2020).

11. Матеріали науково-практичної конференції “Шляхи створення єдиної системи логістики Збройних Сил України за досвідом локальних війн та проведення антитерористичної операції", 27 червня 2018 р. - К.: НУОУ, 2018.

12. Матеріали науково-практичного семінару “Проблемні питання розвитку та організації логістики Збройних Сил України за досвідом проведення антитерористичної операції та розвитку системи логістики у країнах НАТО", 29 червня 2017 р. - К.: НУОУ, 2017.

13. Кривогуз Г. Поняття “Логістика" i його застосування при реформуванні органів управління тилом Збройних Сил України. URL: http://www.nbuv.gov.ua/node/2116 (дата звернення 30.12.2020).

14. Нагорнічевський О. Державне управління реформуванням системи тилового забезпечення Збройних Сил України в 
контексті досвіду країн НАТО. Державне управління та місцеве самоврядування. 2015. № 2(25). С. 191-199.

15. Пунда Ю. В., Гребенюк М. В. Трансформація системи управління збройними силами: досвід США та реалії України. Наука і оборона. 2014. Вип. 4. С. 37-46.

16. Павловський І. В., Твердохлібов В. В., Башкиров О. М. Пропозиції щодо удосконалення системи логістичного забезпечення Збройних Сил України. Озброєння та військова техніка. 2017. Вип. 1(3). C. 51-54.

17. Саган В., Василевський В. Аналіз Особливостей Логістичного Забезпечення Провідних Держав Світу. Збірник наукових праць Національної академії Державної прикордонної служби України Серія: військові та технічні науки. 2017. № 1(71). С. 201-225.

18. Наконечний О. В. Аналіз умов та факторів, що впливають на ефективність функціонування системи логістики сил оборони держави. Системи управління, навігації ma зв'язку. 2019. Вип. 3(55). С. 48-57.

19. Чорнописька Н. В., Брень О. В., Данильців О. І. Зародження військової логістики в Україні. 2015. URL: http://www.nbuv.gov.ua/node/ 2116.

20. Заклад М. А., Утюшев М. К., Бобров С. В. Підходи до автоматизації процесів логістичного забезпечення Збройних Сил України. Збірник наукових праць Центру воєнно-стратегічних досліджень Національного університету оборони України імені Івана Черняховського. 2018. № 3(64). С. 61-64.

21. Кивлюк В. С. Погляди на формування та функціонування системи матеріальнотехнічного забезпечення Збройних сил України. Наука і оборона. 2006. № 2. С. 2225.

22. Кивлюк В .С., Клонцак М. Я., Лоза В. М., Шевченко В. В. Вироблення єдиних поглядів щодо створення сучасної державної системи логістики Збройних Сил України. URL: http://www.nbuv.gov.ua/node/2116 (дата звернення 30.06.2020).
23. Неуров І. В. Постачання та закупівлі у військовій логістиці. Системи озброєння $i$ військова техніка. 2008. Вип. № 2(14). С. 5860.

24. Беляченко В. В., Педан Ф. Ф., Романченко О. А. Підходи до створення, підтримки і вдосконалення АСУ логістичного забезпечення 3С України з урахуванням досвіду країн-членів НАТО. Збірник наукових праць Центру воєнно-стратегічних досліджень Національного університету оборони України імені Івана Черняховського. 2018. Вип. № 3(64). С. 54-60.

25. Сумець О. М. Логістика у збройних силах HATO та Бундесверу, 2012 p. URL: http://logisticstime.com/news/logistika-vvooruzhennyx-silax-nato-i-bundesvera (дата звернення 30.12.2020).

26. Положення про Головне управління логістики Збройних Сил України: Наказ Генерального штабу Збройних Сил України від 16.06.2017p. № 209.

27. Про проведення експерименту зі створення та функціонування системи логістичного забезпечення Збройних Сил України: наказ Генерального штабу Збройних Сил України від 26.03. 2018 р. № 130.

28. Про затвердження Основних положень логістичного забезпечення Збройних Сил України: наказ Міністерства оборони України від 11.10.2016 р.№ 552.

29. Про національну безпеку України: Закон України від 21.06.2018 р. № 2469-VIII URL: https://zakon.rada.gov.ua/laws/show/246919.

30. SCM - управління ланцюжками поставок. ITEnterprise. URL: https://www.it.ua/aboutcompany (дата звернення 30.12.2020).

31. What are RFID and How Does RFID Work? AB\&R's. URL: https://www.abr.com/what-isrfid-how-does-rfid-work/ (дата звернення 30.06.2020).

32. Ніколова О. О. Системи ідентифікації поштових відправлень. Посібник. МОН, Державний університет телекомунікацій. Київ, 2015. С.35.

33. Coalition Autonomous system-the future of military logistics. GOV.UK.2019: веб-сайт. URL: 
https://www.gov.uk/government/news/coaliti on-autonomous-systems-the-future-ofmilitary-logistics (дата звернення 30.06.2020).

34. Сумец О. М. Логістика у збройних силах НАТО та Бундесверу, 2012 p. Logistics time. URL: http://logisticstime.com/news/logistikav-vooruzhennyx-silax-nato-i-bundesvera (дата звернення 30.06.2020).

35. Шульман О. Військова логістика ізраїльської армії. Військо-промисловий кур'єр. 2006. № 6. URL: http://militaryarticle.ru/voennopromishlennii-kurer/2008-vpk/2397-voennajalogistika-izrailskoj-armii (дата звернення 30.06.2020).

36. Сапіга Р., Костюк О. Підходи формування логістичної політики збройних сил НАТО. Тернопіль: ТHTУ ім. І. Пулюя, 2011 р. URL: http://elartu.tntu.ua.pdf (дата звернення 30.06.2020).
37. Allied Joint Doctrine for logistics (2018). NATO. URL: https://nso.nato.int/nso/zPublic/ap/ PROM/AJP-4\%20EDB\%20V1\%20E.pdf (дата звернення 30.06.2020).

38. Под'ячев Д. Як правильно користуватися NPS для виміру лояльності аудиторії. URL: https://ukrsocstandart.com/uk/yak-pravilnokoristuvatisya-nps-dlya-vimir/ (дата звернення 30.06.2020).

39. Karpenko, N., \& Tkach, I. (2020). Geopolitical perspectives of the triangle "Kyiv - Minsk Nur-Sultan", situated on the Chinese "Silk Road" under the "American umbrella". Political Science and Security Studies Journal, 1(1), 5560. https://doi.org/10.5281/zenodo.4284602

40. Tkach I. M. Conceptual principles of military and economic security of the state: monograph. Kyiv, 2018. 312 p.

\title{
Анализ трендов развития науки и технологий в контексте имплементации инструментов современного менеджмента В процесс трансформации логистики Вооруженных сил Украины
}

\author{
Александр Мацко ${ }^{1}$ А; Иван Гаврилюк 1 А \\ ${ }^{1}$ Corresponding author: к.в.н., профессор, начальник института обеспечения войск (сил) и информационных технологий, \\ e-mail: macko2006@ukr.net, ORCID: 0000-0003-3415-3358 \\ ${ }^{2}$ к.в.н., старший научный сотрудник отдела логистических исследований, e-mail: ivan.havryliuk@gmail.com
}

А Национальный университет обороны Украины имени Ивана Черняховского, пр-кт Воздухофлотский, 28, г. Киев, 03049, Украина

\begin{abstract}
Аннотация
Результаты проведенного исследования могут быть полезными для ученых и управленцев всех уровней, исследующие и практически занимаются проблематикой развития логистики не только в секторе безопасности и обороны, но и в государственном секторе в целом. Систематизация литературных источников и подходов к решению проблемы развития военной логистики показала отсутствие четкого алгоритма по ее трансформации и развития. По результатам проведенного исследования идентифицирован ряд факторов, негативно влияют на развитие логистики в Вооруженных Силах Украины. Также, в статье, проанализированы общий смысл логистики ВС Украины, подходы к организации логистики стран-членов НАТО и сформулированы вопросы, требующие первоочередного решения. Уделено значительное внимание глобальным трендам развития науки и технологий, которые могут быть использованы в современной военной логистике. Смоделированы подходы к применению инструментов современного менеджмента в логистике ВС Украины. Определены на основе применения современных инструментов менеджмента требования к перспективной системе логистики ВСУ с формулировкой соответствующего проекта технического задания системы логистики.
\end{abstract}

Ключевые слова: система логистики, логистика Вооруженных Сил Украины, военная логистика, инструменты логистики. 


\title{
Analysis of trends in the development of science and technologies in the context of implementation of modern management instruments in the process of transformation of the logistics of the armed forces of Ukraine
}

\author{
Oleksander Matsko ${ }^{1}$ A; Ivan Havryliuk ${ }^{2}$ A \\ ${ }^{1}$ Corresponding author: Ph.D., Professor, Head of the Institute for Support of Troops (Forces) and Information Technologies, \\ e-mail: macko2006@ukr.net, ORCID: 0000-0003-3415-3358 \\ 2 Ph.D., Senior Research Fellow, Department of Logistics Research, e-mail: ivan.havryliuk@gmail.com \\ A National Defence University of Ukraine named after Ivan Cherniachovskyi, 28, Povitroflotsky, ave, Kyiv, 03049, Ukraine
}

\begin{abstract}
The results of the study can be useful for scientists and managers of all levels, researching and practically dealing with the problems of logistics development not only in the security and defense sector, but also in the public sector as a whole. The systematization of literary sources and approaches to solving the problem of the development of military logistics showed the absence of a clear algorithm for its transformation and development. Based on the results of the study, a number of factors have been identified that negatively affect the development of logistics in the Armed Forces of Ukraine. Also, the article analyzes the general meaning of the logistics of the Ukrainian Armed Forces, approaches to organizing the logistics of NATO member states and formulates issues that require priority solutions. Considerable attention is paid to global trends in the development of science and technology that can be used in modern military logistics. Approaches to the use of modern management tools in the logistics of the Armed Forces of Ukraine are modeled. The requirements for the perspective logistics system of the Armed Forces of Ukraine were determined on the basis of the use of modern management tools with the formulation of the corresponding draft technical specifications for the logistics system.
\end{abstract}

Keywords: logistics system, logistics of the Armed Forces of Ukraine, military logistics, logistics tools.

\section{References}

1. Shlyakhy stvorennya yedynoyi systemy lohistyky Zbroynykh Syl Ukrayiny za dosvidom lokal'nykh viyn ta provedennya antyterorystychnoyi operatsiyi [Ways to create a unified logistics system of the Armed Forces of Ukraine based on the experience of local wars and anti-terrorist operation], naukovopraktychnyy seminar kafedry tylovoho zabezpechennya, Tezy dopovidey, inv. 9188, 2018, $80 \mathrm{~s}$.

2. Kivlyuk , V., Tkach, M., Loishyn , A., \& Gannenko, Y. (2019). Improvement of educational activities in order to develop the logistics system of the Armed forces of Ukraine. Journal of Scientific Papers "Social Development and Security», 9(6), 112-124. DOI: 10.33445/sds.2019.9.6.9

3. Kyvliuk, V., \& Gannenko, Y. (2018).
Improvement of the system of material resources of the armed forces of Ukraine. Journal of Scientific Papers "Social Development and Security», 4(2), 49-58. DOI: 10.5281/zenodo.1231404

4. Dachkovs'kyy V.O. Kontseptual'ni osnovy upravlinnya potokamy v systemi lohistychnoho zabezpechennya Zbroynykh Syl Ukrayiny [Conceptual bases of flow management in the system of logistical support of the Armed Forces of Ukraine] / V.O. Dachkovs'kyy, I.YU. Havrylyuk, O.Y. Mats'ko // naukovyy zhurnal "Suchasni informatsiyni tekhnolohiyi u sferi bezpeky ta oborony", NUOU. 2019. № 1(34) S. $37-44$.

5. Zaklad M. A. Analiz funktsionuvannya systemy lohistyky u providnykh krayinakh svituc[Analysis of the functioning of the 
logistics system in the leading countries of the world,], "Suchasni informatsiyni tekhnolohiyi u sferi bezpeky ta oborony", №3(36), 2019

6. Pro Stratehichnyy oboronnyy byuleten' Ukrayinyc [On the Strategic Defense Bulletin of Ukraine]: Ukaz Prezydenta Ukrayiny vid 20 travnya 2016 r. № 240/2016. Available from: https://www.president.gov.ua/documents/24 02016-20137 (data zvernennya 30.06.2020).

7. Pro Derzhavnu prohramu rozvytku Zbroynykh Syl Ukrayiny na period do 2020 roku [On the State Development Program of the Armed Forces of Ukraine for the period up to 2020]: Ukaz Prezydenta Ukrayiny vid 22 bereznya 2017 r. № 73/2017: Available from: https://zakon.rada.gov.ua/laws/show/n00175 25-16 (data zvernennya 30.06.2020).

8. NATO Logistics Handbook/-Brussels: NATO HQ, 2012. -210.,

9. Christopher R. Paparone, "Defining Analytics and Its Supporting Role in Military Logistics Intelligence". Christopher R. Paparone and George L. Topic Jr / Army Sustainment, September-October 2015.

10. Richna natsional'na prohramy pid ehidoyu Komisiyi Ukrayina - NATO na 2020 rik [Annual National Program under the auspices of the NATO-Ukraine Commission for 2020]: Ukaz Prezydenta Ukrayiny vid 26 travnya 2020 roku № 203/2020. Available from: https://www.president.gov.ua/documents/20 32020-33861 (data zvernennya 30.06.2020).

11. Materialy naukovo-praktychnoyi konferentsiyi "Shlyakhy stvorennya yedynoyi systemy lohistyky Zbroynykh Syl Ukrayiny za dosvidom lokal'nykh viyn ta provedennya antyterorystychnoyi operatsiyi" [Proceedings of the scientific-practical conference "Ways to create a unified logistics system of the Armed Forces of Ukraine based on the experience of local wars and anti-terrorist operation"], 27 chervnya 2018. Kyiv: NUOU, kaf. TIZ, 2018.

12. Materialy naukovo-praktychnoho seminaru "Problemni pytannya rozvytku ta orhanizatsiyi lohistyky Zbroynykh Syl Ukrayiny za dosvidom provedennya antyterorystychnoyi operatsiyi ta rozvytku systemy lohistyky u krayinakh NATO" [Proceedings of the scientific-practical seminar
"Problems of development and organization of logistics of the Armed Forces of Ukraine on the experience of anti-terrorist operation and development of the logistics system in NATO countries], 29 chervnya 2017. Kyiv: NUOU, kaf. TIZ, 2017.

13. Kryvohuz H. Ponyattya "Lohistyka" i yoho zastosuvannya pry reformuvanni orhaniv upravlinnya tylom Zbroynykh Syl Ukrayiny [The concept of "Logistics" and its application in the reform of the rear authorities of the Armed Forces of Ukraine]. Available from: http://www.nbuv.gov.ua/node/2116 (data zvernennya 30.06.2020).

14. Nahornichevs'kyy O. Derzhavne upravlinnya reformuvannyam systemy tylovoho zabezpechennya Zbroynykh Syl Ukrayiny $v$ konteksti dosvidu krayin NATO [State management of the reform of the logistics system of the Armed Forces of Ukraine in the context of the experience of NATO countries]. Derzhavne upravlinnya ta mistseve samovryaduvannya. 2015. Vyp. 2(25). S. 191199.

15. Punda YU. V., Hrebenyuk M. V. Transformatsiya systemy upravlinnya zbroynymy sylamy: dosvid SSHA ta realiyi Ukrayiny [Transformation of the Armed Forces Management System: US Experience and Realities of Ukraine]. Nauka i oborona. 2014. Vyp. 4. S. 37-46.

16. Pavlovs'kyy I. V., Tverdokhlibov V. V., Bashkyrov O. M. Propozytsiyi shchodo udoskonalennya systemy lohistychnoho zabezpechennya Zbroynykh Syl Ukrayiny [Proposals for improving the logistics system of the Armed Forces of Ukraine]. Ozbroyennya ta viys'kova tekhnika. 2017. Vyp. 1(3). S. 51-54.

17. Sahan V., Vasylevs'kyy V. Analiz Osoblyvostey Lohistychnoho Zabezpechennya Providnykh Derzhav Svitu [Analysis of the Features of Logistics Support of the Leading States of the World]. Zbirnyk naukovykh prats' Natsional'noyi akademiyi Derzhavnoyi prykordonnoyi sluzhby Ukrayiny Seriya: viys'kovi ta tekhnichni nauky. 2017. Vyp. 1(71). S. 201-225.

18. Nakonechnyy O. V. Analiz umov ta faktoriv, 
shcho vplyvayut' na efektyvnist'

funktsionuvannya systemy lohistyky syl oborony derzhavy [Analysis of conditions and factors influencing the efficiency of the logistics system of the state defense forces]. Systemy upravlinnya, navihatsiyi ta zv'yazku. 2019. Vyp. 3(55). S. 48-57.

19. Chornopys'ka N. V., Bren' O. V., Danyl'tsiv O. I. Zarodzhennya viys'kovoyi lohistyky v Ukrayini [Origin of military logistics in Ukraine]. 2015. Available from: http://www.nbuv.gov.ua/node/2116.

20. Zaklad M. A., Utyushev M. K., Bobrov S. V. Pidkhody do avtomatyzatsiyi protsesiv lohistychnoho zabezpechennya Zbroynykh Syl Ukrayiny [Approaches to automation of processes of logistical support of the Armed Forces of Ukraine]. Zbirnyk naukovykh prats' Tsentru voyenno-stratehichnykh doslidzhen' Natsional'noho universytetu oborony Ukrayiny imeni Ivana Chernyakhovs'koho. 2018. Vyp. № 3(64). S. 61-64.

21. Kyvlyuk V. S. Pohlyady na formuvannya ta funktsionuvannya systemy material'notekhnichnoho zabezpechennya Zbroynykh syl Ukrayiny [Views on the formation and functioning of the logistics system of the Armed Forces of Ukraine]. Nauka i oborona. 2006. Vyp. 2. S. 22-25.

22. Kyvlyuk V. S., Klontsak M. YA., Loza V. M., Shevchenko V. V. Vyroblennya yedynykh pohlyadiv shchodo stvorennya suchasnoyi derzhavnoyi systemy lohistyky Zbroynykh Syl Ukrayiny [Development of common views on the creation of a modern state logistics system of the Armed Forces of Ukraine]. Available from: http://www.nbuv.gov.ua/node/2116 (data zvernennya 30.06.2020).

23. Neurov I. V. Postachannya ta zakupivli u viys'koviy lohistytsi [Supply and procurement in military logistics]. Systemy ozbroyennya i viys'kova tekhnika. 2008. Vyp. № 2(14). S. 5860.

24. Belyachenko V. V., Pedan F. F., Romanchenko O. A.. Pidkhody do stvorennya, pidtrymky $i$ vdoskonalennya ASU lohistychnoho zabezpechennya ZS Ukrayiny z urakhuvannyam dosvidu krayin-chleniv NATO [Approaches to the creation, support and improvement of AMS logistics of the Armed Forces of Ukraine, taking into account the experience of NATO member countries]. Zbirnyk naukovykh prats' Tsentru voyenno-stratehichnykh doslidzhen' Natsional'noho universytetu oborony Ukrayiny imeni Ivana Chernyakhovs'koho. 2018. Vyp. № 3(64). S. 54-60.

25. Sumets' O. M. Lohistyka u zbroynykh sylakh NATO ta Bundesveru [Logistics in the Armed Forces of NATO and the Bundeswehr], 2012. Available from: http://logisticstime.com/news/logistika-vvooruzhennyx-silax-nato-i-bundesvera (data zvernennya 30.06.2020).

26. Polozhennya pro Holovne upravlinnya lohistyky Zbroynykh Syl Ukrayiny [Regulations on the Main Logistics Department of the Armed Forces of Ukraine]: Nakaz Heneral'noho shtabu Zbroynykh Syl Ukrayiny vid 16.06.2017r. № 209.

27. Pro provedennya eksperymentu zi stvorennya ta funktsionuvannya systemy lohistychnoho zabezpechennya Zbroynykh Syl Ukrayiny [On conducting an experiment on the creation and operation of the logistics system of the Armed Forces of Ukraine]: nakaz Heneral'noho shtabu Zbroynykh Syl Ukrayiny vid 26.03. 2018 r. № 130.

28. Pro zatverdzhennya Osnovnykh polozhen' lohistychnoho zabezpechennya Zbroynykh Syl Ukrayiny [On approval of the Basic Provisions of Logistics Support of the Armed Forces of Ukraine]: nakaz Ministerstva oborony Ukrayiny " vid 11.10.2016 r.№ 552.

29. Pro natsional'nu bezpeku Ukrayiny [On National Security of Ukraine]: Zakon Ukrayiny vid 21.06.2018 r. № 2469-VIII. Available from: https://zakon.rada.gov.ua/laws/show/246919.

30. SCM - upravlinnya lantsyuzhkamy postavok. IT-Enterprise [SCM - supply chain management]: Available from: https://www.it.ua/about-company (data zvernennya 30.06.2020).

31. What is RFID and How Does RFID Work? AB\&R's : Available from: https://www.abr.com/what-is-rfid-how-does- 
rfid-work/ (data zvernennya 30.06.2020).

32. Nikolova O. O. Systemy identyfikatsiyi poshtovykh vidpravlen' [Systems of identification of postal items]. Posibnyk. MON, Derzhavnyy universytet telekomunikatsiy. Kyiv, 2015. S.35.

33. Coalition Autonomous system - the future of military logistics. GOV.UK.2019: веб-сайт. Available from: https://www.gov.uk/ government/news/coalition-autonomoussystems-the-future-of-military-logistics.

34. Sumets O. M. Lohistyka u zbroynykh sylakh NATO ta Bundesveru [ogistics in the NATO and Bundeswehr Armed Forces], 2012 r. Logistics time: veb-sayt. Available from: http://logisticstime.com/news/logistika-vvooruzhennyx-silax-nato-i-bundesvera (data zvernennya 30.06.2020).

35. Shul'man O. Viys'kova lohistyka izrayil's'koyi armiyi. Viys'ko-promyslovyy kur"yer [Military logistics of the Israeli army]. 2006. Vyp. № 6. Available from: http://militaryarticle.ru/ voenno-promishlennii-kurer/2008-vpk/2397voennaja-logistika-izrailskoj-armii (data zvernennya 30.06.2020).

36. Sapiha R., Kostyuk O. Pidkhody formuvannya lohistychnoyi polityky zbroynykh syl NATO [Approaches to the formation of logistics policy of the NATO armed forces]. Ternopil': TNTU im. I. Pulyuya, 2011 r. Available from: http://elartu.tntu.ua.pdf (data zvernennya 30.06.2020).

37. Allied Joint Doctrine for logistics (2018). NATO: Available from: https://nso.nato.int/nso/ zPublic/ap/PROM/AJP-4\%20EDB\%20V1\% 20E.pdf (data zvernennya 30.06.2020).

38. Pod"yachev D. Yak pravyl'no korystuvatysya NPS dlya vymiru loyal'nosti audytoriyi [How to properly use NPS to measure audience loyalty]. Available from: https://ukrsocstandart.com/ uk/yak-pravilno-koristuvatisya-nps-dlya-vimir/ (data zvernennya 30.06.2020)

39. Karpenko, N., \& Tkach, I. (2020). Geopolitical perspectives of the triangle "Kyiv - Minsk Nur-Sultan", situated on the Chinese "Silk Road" under the "American umbrella". Political Science and Security Studies Journal, 1(1), 5560. https://doi.org/10.5281/zenodo.4284602

40. Tkach I.M. Conceptual principles of military and economic security of the state: monograph. Kyiv, 2018. 312 p. 